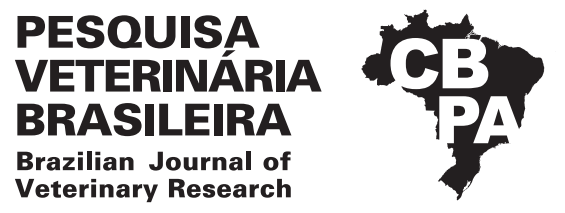

Pesq. Vet. Bras. 38(12):2217-2223, dezembro 2018 DOI: 10.1590/1678-5150-PVB-6075

Original Article

Animais de Produção/Livestock Diseases

ISSN 0100-736X (Print)

ISSN 1678-5150 (Online)

\title{
Economic losses due to Vernonia rubricaulis poisoning in cattle ${ }^{1}$
}

\author{
Marcelo Cezar Soares ${ }^{2}$, Rayane C. Pupin², Carolina C. Guizelini² ${ }^{2}$ Alberto O. Gaspar², \\ Danilo C. Gomes ${ }^{2}$, Ricardo C. Brumatti ${ }^{2}$ and Ricardo A.A. Lemos ${ }^{2 *}$
}

\begin{abstract}
Soares M.C., Pupin R.C., Guizelini C.C., Gaspar A.O., Gomes D.C., Brumatti R.C. \& Lemos R.A.A. 2018. Economic losses due to Vernonia rubricaulis poisoning in cattle. Pesquisa Veterinária Brasileira 38(12):2217-2223. Faculdade de Medicina Veterinária e Zootecnia, Universidade Federal de Mato Grosso do Sul, Avenida Senador Felinto Muller 2443, Jardim Parati, Campo Grande, MS 79070-900, Brazil. E-mail: marcelocezar@outlook.com

Vernonia rubricaulis is a hepatotoxic plant found in the Pantanal biome. Under natural conditions, it is responsible for highly fatal poisonings in cattle. From January 1999 to December 2016, 33 outbreaks of $V$. rubricaulis poisoning were recorded, resulting in 1509 bovine deaths, of which 719 (47.6\%) were adult females, 413 (27.4\%) were adult males, $244(16.2 \%)$ adult cattle with no information about sex and $133(8.8 \%)$ calves. The coefficients of morbidity, mortality and lethality were respectively $2.79 \%, 2.77 \%$ and $99.24 \%$. Most outbreaks occurred in properties containing up to 1,000 cattle, where the most significant economic impacts were also observed. Among the total recorded deaths, the total direct monetary loss was estimated at US $\$ 764,893.33$, which represents an average of 3.05\% of the total assets (US $\$ 25,090,683.51$ ) of the herds involved in the outbreaks. The plant can cause more severe damage to properties with less than 500 cattle, and can reach $50 \%$ of the total value of the herd. In comparison to other methods, the methodology used in this study has an economic impact consistent with reality, not overestimating the losses. Toxic plants, such as V.rubricaulis, can cause significant economic losses in the extensive systemic livestock, and it is important decision-making and prophylactic management to avoid the occurrence of poisoning in the herds.
\end{abstract}

INDEX TERMS: Economic losses, cattle, poisoning, Vernonia rubricaulis, bovine diseases, economic impact, plant poisoning, toxicoses.

RESUMO.- [Perdas econômicas causadas pela intoxicação por Vernonia rubricaulis em bovinos.] Vernonia rubricaulis é uma planta hepatotóxica encontrada no bioma Pantanal. Em condições naturais, é responsável por intoxicações altamente fatais em bovinos. De janeiro de 1999 a dezembro de 2016, foram registrados 33 surtos de intoxicação por $V$. rubricaulis em bovinos que resultaram em 1509 mortes, sendo $719(47,6 \%)$ fêmeas adultas, $413(27,4 \%)$ machos adultos, $244(16,2 \%)$ bovinos adultos sem informação sobre o sexo e 133 (8,8\%) bezerros. Os coeficientes de morbidade, mortalidade e letalidade foram respectivamente de $2,79 \%$, $2,77 \%$ e $99,24 \%$. A maioria dos surtos ocorreu em propriedades

\footnotetext{
${ }^{1}$ Received on August 13, 2018.

Accept for publication on August 20, 2018.

${ }^{2}$ Faculdade de Medicina Veterinária e Zootecnia (FAMEZ), Universidade Federal de Mato Grosso do Sul (UFMS), Avenida Senador Felinto Muller 2443, Jardim Parati, Campo Grande, MS 79070-900, Brazil. *Corresponding author: ricardo.lemos@ufms.br
}

contendo até mil bovinos, onde também foram constatados os impactos econômicos mais significativos. Do total das mortes registradas, o prejuízo monetário direto total foi calculado em US\$764.893,33, o que representa em média 3,05\% do total do patrimônio (US $\$ 25.090 .683,51$ ) dos rebanhos envolvidos nos surtos. A planta pode causar prejuízos mais severos em propriedades com menos de 500 bovinos, podendo chegar a $50 \%$ do total do valor do rebanho. Em comparação aos outros métodos, a metodologia utilizada neste estudo afere um impacto econômico condizente com a realidade, não superestimando os prejuízos. Plantas tóxicas, como a V. rubricaulis, podem causar prejuízos econômicos significativos na pecuária extensiva, sendo importantes tomadas de decisões e manejos profiláticos para evitar a ocorrência de intoxicação nos rebanhos.

TERMOS DE INDEXAÇÃO: Perdas econômicas, intoxicação, Vernonia rubricaulis, doenças de bovinos, impacto econômico, intoxicações por plantas, toxicoses. 


\section{INTRODUCTION}

In countries where livestock farming is based on an extensive system, there is an increase in the possibility of cattle access to toxic plants, and consequently increases the incidence of poisoning by plants (Pessoa et al. 2013). One of the main plants associated with cattle poisoning in the Pantanal region is Vernonia rubricaulis, a sub-bush of the Asteracea family whose development occurs in areas subject to temporary flooding, in places of brackish water or in clayey soils (Purisco \& Lemos 2008, Lemos et al. 2011). The toxic principle is unknown and, under natural conditions, poisoning occurs only in cattle, while experimentally, it was toxic to sheep (Souza et al. 2015, Godoy et al. 2018). In the budding stage, V. rubricaulis is more toxic and more palatable, which favors poisoning (Tokarnia \& Döbereiner 1982, Brum et al. 2002, Tokarnia et al. 2012, Godoy et al. 2018).

Although there are methodologies that estimate the direct and indirect damage caused by toxic plants in a particular region or country (James et al. 1992, Riet-Correa \& Medeiros 2001), there are no detailed reports on the economic losses caused by these poisonings on the properties in that they occur. This approach requires the joint analysis of the economic parameters with the epidemiological data of the outbreaks, and can be used to assess mortality losses in herds due to other causes (Smith 1998, Pötter et al. 2000, Gottschall et al. 2010). The evaluation of the economic impact of health problems is important in the search for a production system that is more economically profitable and constitutes an important tool for guiding the herd management (Dijkhuizen et al. 1995, Perry et al. 2001, FAO 2016).

The objective of this study is to develop a model, based on spontaneous cases of $V$. rubricaulis, to estimate the economic losses resulting from the mortality caused in cattle by ingestion of toxic plants in extensive production systems.

\section{MATERIALS AND METHODS}

The necropsies performed in cattle from January 1999 to December 2016 at the Laboratory of Pathology Anatomy of the Federal University of Mato Grosso do Sul (LAP-UFMS) were reviewed.

The cases of poisoning were selected by Vernonia rubricaulis obeying the following criteria previously described by Brum et al. (2002): 1) evidence of ingestion of the plant by cattle, 2) confirmation by on-site visits by the team, 3) characteristic clinical signs, necropsy findings, and histopathology consistent with severe or massive centrolobular hepatic necrosis and multifocal bleeding.

Data relating to the total number of cattle on farms and the quantities of sick and dead cattle were collected from the reports. For economic analysis, cases from the same property and from the same period were grouped with a single outbreak.

For the epidemiological analysis, the coefficients of morbidity, mortality and lethality were calculated for each property, considering the number of animals affected and dead due to poisoning in relation to the other cattle raised under the same conditions of nutritional and sanitary management. The numeric data of diseased and dead animals corresponded to the time of sending the material.

The economic assessment was based on data on the total number of animals on the farm and on the number of animals killed, as well as on the composition of the herds and the category of affected animals, thus correcting their values to obtain a weighted average of carcass weight.
The price of the animals was calculated on the basis of the price of the kilogram (kg) of the carcass of the bull through research and analysis of the prices during the entire period of the outbreaks.

The price of adult male bovines was estimated with the average price per kg of the Boi Gordo Indicator of the Center for Advanced Studies in Applied Economics of the "Luiz de Queiroz" College of Agriculture - University of São Paulo/Stock Exchange, Commodities and Futures of the São Paulo Stock Exchange (CEPEA Esalq/BM \& FBovespa) for the year 2017.

In order to calculate the average value of adult females, the difference in percentage between the values paid for fat cows and for cattle was calculated, referring to the average kilogram paid to the producer, as informed by the Indicator of the Mato Grosso South (CEASA) in 2017. All animals less than 12 months of age were considered calves and the mean value for this animal category was calculated by the difference in percentage between the values paid by CEPALE Esalq/BM \& FBovespa Mato Calf Indicator Grosso do Sul in 2017 and the price of the cattle, being converted into the price of the kilogram of the carcass.

In order to estimate the monetary values and consequently the economic losses, the quotations used were converted from the real to the US dollar using the average value of the exchange rate for the year 2017 obtained from the Central Bank of Brazil.

In order to price the different animal categories of cattle, the following values were calculated:

$$
\$ V m a=\left(L W_{m a} * C Y\right) * P k g_{m a}
$$

In which: $\$ \mathrm{Vma}=$ the average unit monetary value of adult animals, $\mathrm{LWma}=$ the estimated average live weight of adult males $(400 \mathrm{~kg})$, $\mathrm{CY}=$ the estimated carcass yield (50\%), Pkgma $=$ the average kilogram price of the fattened carcass paid to the producer.

$$
\$ V f a=\left(L W_{f a} * C Y\right) * P k g_{f a}
$$

In that: $\$ \mathrm{Vfa}=$ average unit monetary value of adult females, LWfa $=$ estimated average live weight of adult females $(360 \mathrm{~kg})$, $\mathrm{CY}=$ estimated carcass yield $(50 \%), \mathrm{Pkgfa}=$ average price of kilograms of cow carcass paid to producer

$$
\$ V a a=(\$ V m a+\$ V f a) / 2
$$

In which: \$ Vaa = unit average monetary value of adult animals where sex was not reported, $\$ \mathrm{Vma}=$ unit average monetary value of adult males, \$ Vfa = average unit monetary value of adult females.

$$
\$ V c a=\left(L W_{c a} * C Y\right) * P k g_{c a}
$$

In which: $\$ \mathrm{Vca}=$ the average unit value of the calves, $\mathrm{LWca}=$ the estimated average live weight of the calves up to 1 year of age $(180 \mathrm{~kg})$, $\mathrm{CY}=$ estimated carcass yield $(50 \%), \%$ Pkgca $=$ of the calf.

To calculate the other values needed for the analyzes, the following equations were used:

$$
\$ V m=(V m a+V f a+V a a+C a) / 4
$$

In which: $\mathrm{Vm}=$ the average unit monetary value of the herd, $\mathrm{Vma}=$ the unit average monetary value of the adult male animals, $\mathrm{Vfa}=$ the average unit monetary value of the female adult animals, Vaa = the average unit monetary value of adult animals with uninformed sex, $\mathrm{Ca}=$ the average monetary value of the calf.

$$
\$ V t h=n * \$ V m
$$


In which: $\$$ Vth $=$ monetary value of the total herd in the property, $\mathrm{n}=$ total amount of the herd, $\$ \mathrm{Vm}=$ the average unit monetary value of the herd.

$$
\$ T E c L=n d * \$ V u
$$

In which: $\$ \mathrm{TEcL}=$ total economic loss related to deaths, $\mathrm{nd}=$ total number of dead animals, $\$ \mathrm{Vu}=$ unit commercial value of reported category.

$$
\% E c L=((\$ T E c L / \$ V t h) * 100)
$$

In which:\% $\% \mathrm{EcL}=$ percentage of estimated economic loss, $\$ \mathrm{TEcL}=$ total economic loss related to deaths, $\$ \mathrm{Vth}=$ monetary value of the total herd in the property.

\section{RESULTS}

All outbreaks of poisoning by Vernonia rubricaulis occurred in the western region of the state of Mato Grosso do Sul, Brazil (Fig.1), where the Pantanal biome is located, the largest water-covered plain in the world with chemically poor soils and limited fertility (Furlan et al. 2012).

A total of 1509 cattle were killed, of which 719 (47.6\%) were adult females, 413 (27.4\%) were adult males, 244 (16.2\%) were adult animals in which sex was not informed and 133
(8.8\%) calves from 0 to 12 months of age (Table 1 ). In 26 of the 33 outbreaks studied, the epidemiological information was complete, thus, the morbidity, mortality and lethality

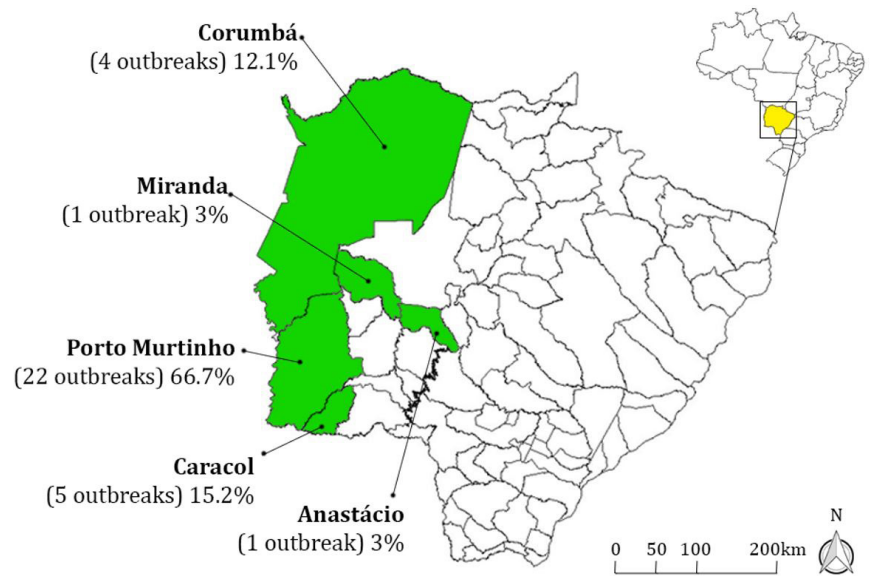

Fig.1. Geographical location of occurrences of outbreaks of poisoning by Vernonia rubricaulis in cattle in Mato Grosso do Sul.

Table 1. Epidemiological data on outbreaks of food poisoning by Vernonia rubricaulis in cattle diagnosed in the LAP/FAMEZ

\begin{tabular}{|c|c|c|c|c|c|c|c|c|}
\hline Outbreak & Year & Month & City & Age (months) & Total of cattles & $\begin{array}{c}\text { Number of sick } \\
\text { cattles }\end{array}$ & $\begin{array}{c}\text { Number of } \\
\text { dead cattles }\end{array}$ & Gender \\
\hline 1 & 1999 & September & Porto Murtinho & Aa. & 2300 & 114 & 114 & $7 \mathrm{M} / 107 \mathrm{~F}$ \\
\hline 2 & 1999 & October & Porto Murtinho & $30-36$ & 2700 & 150 & 150 & $\mathrm{~F}$ \\
\hline 3 & 1999 & October & Porto Murtinho & Aa. & 4500 & 200 & 200 & $\mathrm{NI}$ \\
\hline 4 & 1999 & October & Porto Murtinho & Aa. & NI & 6 & 6 & $\mathrm{NI}$ \\
\hline 5 & 1999 & October & Porto Murtinho & Aa. & 300 & 17 & 17 & NI \\
\hline 6 & 1999 & October & Porto Murtinho & Aa. & 2500 & 60 & 60 & $\mathrm{~F}$ \\
\hline 7 & 1999 & November & Corumbá & 30 & 1500 & 104 & 104 & $\mathrm{~F}$ \\
\hline 8 & 1999 & November & Caracol & 30 & 200 & 7 & 6 & M \\
\hline 9 & 1999 & December & Porto Murtinho & 30 & $\mathrm{NI}$ & 8 & 8 & $\mathrm{NI}$ \\
\hline 10 & 2000 & February & Porto Murtinho & $1-3$ & 380 & 13 & 13 & $\mathrm{NI}$ \\
\hline 11 & 2000 & March & Porto Murtinho & $1-8$ & 3000 & 16 & 16 & NI \\
\hline 12 & 2000 & May & Porto Murtinho & 18 & 121 & 2 & 2 & M \\
\hline 13 & 2000 & August & Miranda & 60 & 2000 & 7 & 7 & $\mathrm{~F}$ \\
\hline 14 & 2000 & November & Porto Murtinho & 36 & 165 & 68 & 68 & M \\
\hline 15 & 2000 & November & Porto Murtinho & 24 & 815 & 30 & 30 & M \\
\hline 16 & 2001 & May & Caracol & 30 & 4000 & 120 & 120 & $\mathrm{~F}$ \\
\hline 17 & 2002 & October & Corumbá & 18 & $\mathrm{NI}$ & $\mathrm{NI}$ & NI & NI \\
\hline 18 & 2002 & October & Porto Murtinho & 36 & 4000 & 69 & 69 & M \\
\hline 19 & 2002 & October & Caracol & 18 & 200 & 13 & 10 & $\mathrm{NI}$ \\
\hline 20 & 2002 & November & Anastácio & 2 & 1400 & $\mathrm{NI}$ & 4 & $\mathrm{NI}$ \\
\hline 21 & 2002 & December & Porto Murtinho & 24 & 400 & 1 & 1 & $\mathrm{~F}$ \\
\hline 22 & 2003 & May & Corumbá & $1-3$ & 1300 & 35 & 35 & $\mathrm{NI}$ \\
\hline 23 & 2004 & September & Porto Murtinho & 48 & 4000 & 68 & 62 & $\mathrm{~F}$ \\
\hline 24 & 2005 & November & Porto Murtinho & 36 & $\mathrm{NI}$ & $\mathrm{NI}$ & NI & $\mathrm{NI}$ \\
\hline 25 & 2006 & February & Porto Murtinho & $6-12$ & $\mathrm{NI}$ & $\mathrm{NI}$ & 60 & $\mathrm{NI}$ \\
\hline 26 & 2006 & March & Porto Murtinho & 24 & 8000 & 80 & 80 & $\mathrm{M}$ \\
\hline 27 & 2008 & October & Porto Murtinho & Aa. & 2200 & 55 & 55 & M \\
\hline 28 & 2009 & September & Caracol & 36 & 581 & 11 & 10 & M \\
\hline 29 & 2010 & November & Porto Murtinho & 24 & 400 & 36 & 36 & M \\
\hline 30 & 2011 & April & Corumbá & 36 & 1200 & 50 & 50 & M \\
\hline 31 & 2012 & February & Porto Murtinho & Aa. & $\mathrm{NI}$ & $\mathrm{NI}$ & 3 & $\mathrm{NI}$ \\
\hline 32 & 2013 & October & Caracol & Aa. & 4500 & 108 & 108 & $\mathrm{~F}$ \\
\hline 33 & 2016 & March & Porto Murtinho & $4-12$ & 350 & 5 & 5 & $\mathrm{NI}$ \\
\hline
\end{tabular}
from 1999 to 2016

$\mathrm{NI}=$ not reported, $\mathrm{M}=$ male, $\mathrm{F}=$ female, $\mathrm{Aa}$. = adult animals (over 12 months), where the exact age was not reported. 
coefficients were respectively $2.79 \%, 2.77 \%$ and $99.24 \%$, respectively.

Once the epidemiological values were structured, it was possible to apply the economic formulas for each affected animal category in cases of poisoning by $V$. rubricaulis in cattle diagnosed in the LAP/FAMEZ university from 1999 to 2016, thus obtaining the mean values considered for calculating the losses generated (Table 2).

The value of the total stockholders' equity of the herds studied in the properties where the outbreaks occurred, totaled US $\$ 25,047,887.39$, considering the average unit monetary value of US $\$ 472.49$. The 1509 recorded deaths correspond to a loss of US $\$ 756,915.74$, which represents $3.02 \%$ in relation to the value of the assets of the herds studied (Table 3 ).

The results of the analysis of the data by classes of occurrences are presented below showing the ranges of higher frequencies for the Total Value of the Herd those less than US $\$ 500,000.00$ in which the total loss was less than US $\$ 20,000.00$ and the percentage value of the loss in relation to the total value of the herd relative to the herd less than $10 \%$ (Fig.2-4).

Table 2. Average results of monetary values applied for each animal category present in cases of poisoning by Vernonia rubricaulis in cattle diagnosed in the LAP/FAMEZ from 1999 to 2016 according to the average price of 2017

\begin{tabular}{lcc}
\hline \multicolumn{1}{c}{ Category } & Average value per kilogram of carcass (US \$/kg) & Average value per animal (US\$) \\
\hline Males adults & 2.892 & 578.32 \\
Female adults & 2.698 & 485.62 \\
Adult animals (gender was not informed) & 2.795 & 531.97 \\
Calves & 3.267 & 294.08 \\
Average unit monetary value (\$Vm) & & 472.49
\end{tabular}

Average of the quotation of the dollar to the real, Brazilian currency (2017) of R\$3.1826.

Table 3. Results of the economic analysis of cases of poisoning by Vernonia rubricaulis in cattle diagnosed in the LAP/FAMEZ from 1999 to 2016 according to the average price of 2017

\begin{tabular}{|c|c|c|c|c|c|}
\hline Case & Total of cattles & Dead cattles & Total value of herd US\$ & Total loss US\$ & $\begin{array}{c}\text { Damage } \\
\%\end{array}$ \\
\hline 1 & 2300 & 114 & $1,086,737.74$ & $56,009.08$ & 5.15 \\
\hline 2 & 2700 & 150 & $1,275,735.61$ & $72,842.30$ & 5.71 \\
\hline 3 & 4500 & 200 & $2,126,226.01$ & $106,393.53$ & 5.00 \\
\hline 4 & NI & 6 & - & $3,191.81$ & - \\
\hline 5 & 300 & 17 & $141,748.40$ & $9,043.45$ & 6.38 \\
\hline 6 & 2500 & 60 & $1,181,236.67$ & $29,136.92$ & 2.47 \\
\hline 7 & 1500 & 104 & $708,742.00$ & $50,503.99$ & 7.13 \\
\hline 8 & 200 & 6 & $94,498.93$ & $3,469.92$ & 3.67 \\
\hline 9 & $\mathrm{NI}$ & 8 & - & $4,255.74$ & - \\
\hline 10 & 380 & 13 & $179,547.97$ & $3,822.98$ & 2.13 \\
\hline 11 & 3000 & 16 & $1,417,484.01$ & $4,705.21$ & 0.33 \\
\hline 12 & 121 & 2 & $57,171.85$ & $1,156.64$ & 2.02 \\
\hline 13 & 2000 & 7 & $944,989.34$ & $3,399.31$ & 0.36 \\
\hline 14 & 165 & 68 & $77,961.62$ & $39,325.76$ & 50.44 \\
\hline 15 & 815 & 30 & $385,083.16$ & $17,349.60$ & 4.51 \\
\hline 16 & 4000 & 120 & $1,889,978.68$ & $58,273.84$ & 3.08 \\
\hline 18 & 4000 & 69 & $1,889,978.68$ & $39,904.08$ & 2.11 \\
\hline 19 & 200 & 10 & $94,498.93$ & $5,319.68$ & 5.63 \\
\hline 20 & 1400 & 4 & $661,492.54$ & $1,176.30$ & 0.18 \\
\hline 21 & 400 & 1 & $188,997.87$ & 485.62 & 0.26 \\
\hline 22 & 1300 & 35 & $614,243.07$ & $10,292.65$ & 1.68 \\
\hline 23 & 4000 & 62 & $1,889,978.68$ & $30,108.15$ & 1.59 \\
\hline 25 & $\mathrm{NI}$ & 60 & - & $17,644.54$ & - \\
\hline 26 & 8000 & 80 & $3,779,957,35$ & $46,265.60$ & 1.22 \\
\hline 27 & 2200 & 55 & $1,039,488.27$ & $31,807.60$ & 3.06 \\
\hline 28 & 581 & 10 & $274,519.40$ & $5,783.20$ & 2.11 \\
\hline 29 & 400 & 36 & $188,997.87$ & $20,819.52$ & 11.02 \\
\hline 30 & 1200 & 50 & $566,993.60$ & $28,916.00$ & 5.10 \\
\hline 31 & $\mathrm{NI}$ & 3 & - & $1,595.90$ & - \\
\hline 32 & 4500 & 108 & $2,126,226.01$ & $52,446.45$ & 2.47 \\
\hline 33 & 350 & 5 & $165,373.13$ & $1,470.38$ & 0.89 \\
\hline TOTAL & 53012 & 1506 & $25,047,887.39$ & $756,915.74$ & 3.02 \\
\hline
\end{tabular}

Average of the quotation of the dollar to the real, Brazilian currency (2017) of R\$3.1826; NI = not informed. 


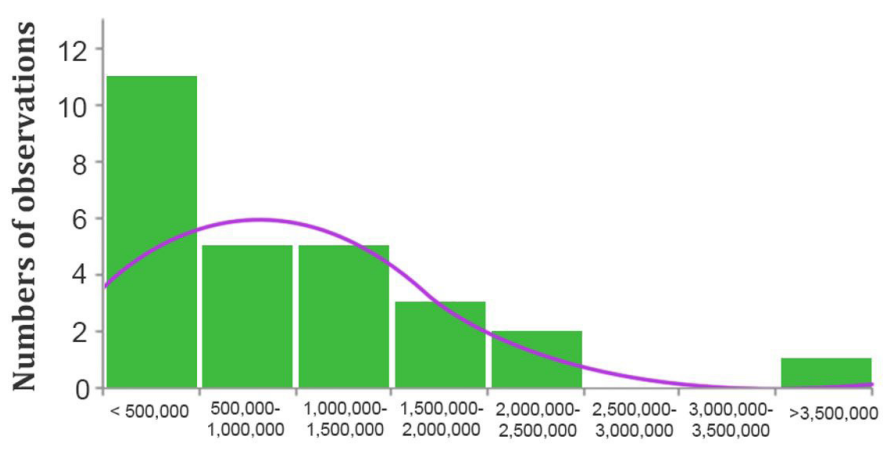

Monetary value of the herd (US\$)

Fig.2. Number of observations referring to the frequency of outbreaks according to the total monetary value of the herds.

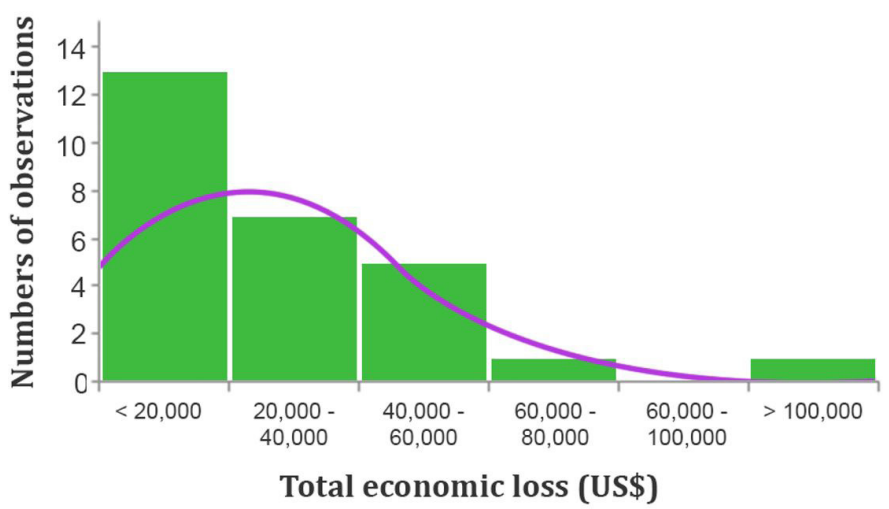

Fig.3. Number of observations referring to the frequency of outbreaks according to the monetary value of the total loss due to poisoning deaths by Vernonia rubricaulis.

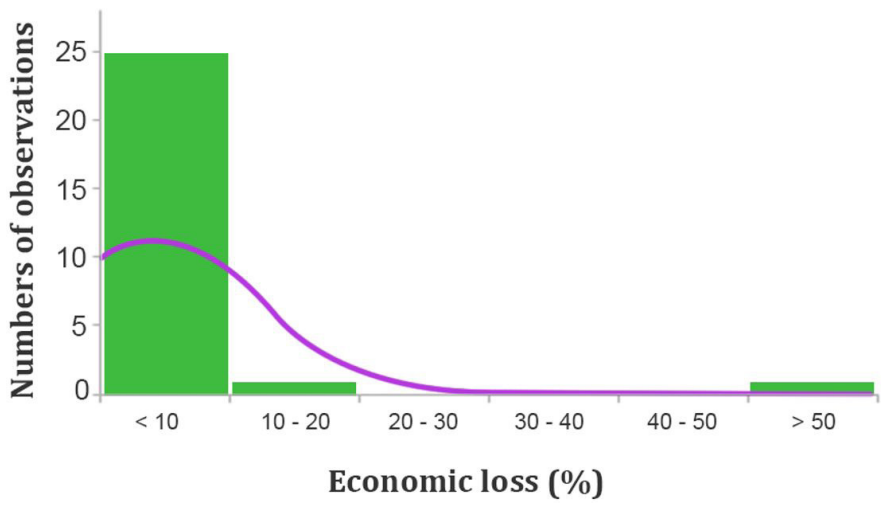

Fig.4. Number of observations of outbreaks in relation to the percentage of injury considering the total monetary value of the herd.

\section{DISCUSSION}

Poisoning by Vernonia rubricaulis was diagnosed in 15 of the 16 years investigated, proving to be a frequent and constant cause of economic losses for the cattle ranch in the state of Mato Grosso do Sul. All outbreaks occurred in an area of 94,067 square kilometers corresponding to five municipalities, the equivalent of $26.3 \%$ of the total area of the state, with all outbreaks analyzed in the Brazilian Pantanal region. In all outbreaks analyzed in this study, 1,509 cattle of all categories were killed, resulting in a total estimated loss of US\$756,915.74.

So far, the reports regarding poisoning by $V$. rubricaulis (Tokarnia \& Döbereiner 1982, Brum et al. 2002, Pessoa et al. 2013) describe the epidemiological, clinical and pathological aspects of the outbreaks, mentioning the total number of deaths, but do not address historical series nor estimate the economic damages caused by poisoning. The methodology adopted in the present study allows estimating the losses caused by poisoning in each property or in a set of properties, determining how much these represent on the total herd patrimony. The methodologies used in previous studies on economic losses caused by plant poisoning in production animals only evaluate the losses, without defining the methodology used (Zhao et al.2013), or only determine the economic impact in certain regions (Nielsen 1978, Riet-Correa \& Medeiros 2001), in a country (Nielsen 1988, Riet-Correa \& Medeiros 2001, Pessoa et al. based on fictitious mortality rates close to $5 \%$.

These studies are important for estimating the total losses from plant poisoning and thus directing public policies to minimize the damages caused by these poisonings. Moreover, studies aiming to determine the losses that occur in each individual property are important to guide decision making by each producer regarding the adoption of measures of control and prophylaxis of these poisonings. Of the 33 outbreaks studied, 15 occurred in 1999 and 2000, when there were large burnings in the region, which favor the budding of the plant and consequently the occurrence of poisoning, because at this stage, in addition to its toxicity, the plant is more palatable to animals (Tokarnia \& Döbereiner 1982, Brum et al. 2002, Godoy et al. 2018).

In the present study, most of the outbreaks that were reported, they occurred on farms where the value of the assets found characterized medium-sized properties for the region's standards. As a result, the chances of the losses being high and more significant for the activity are higher. The two outbreaks in which the highest losses $(50.44 \%$ and $11.02 \%$ of losses related to the total herd equity) were observed in herds with less than 500 herds. These occurrences can make business continuity unfeasible (Nielsen 1988). This type of observation is not detected when collection methods are used that evaluate the total data of the reported outbreaks without stratifying them by properties in which the outbreaks occurred.

Corroborating this point, the analysis of the results obtained in the classes of Total Loss and Relative Percentage Loss show, by property, that the majority of occurrences is at the level of up to $10 \%$ of estimated loss by total of equity informed, however that such percentage level may reach values of up to $\$ 60,000.00$ for rural property. This type of analysis does not appear in general epidemiological studies on plant poisoning (Rissi et al. 2007, Souza et al.2015), or even in specific studies of a particular plant (Carvalho et al. 2006, Carmo et al. 2011).

The mean morbidity coefficient was $2.79 \%$, however, it is worth noting the large variation of the same from $0.25 \%$ to $41.21 \%$. This observation, together with the geographic distribution of the outbreaks, restricted to a specific region of the state, shows that the methodologies for assessing 
losses caused by plant poisoning should consider these particularities. (Riet-Correa \& Medeiros 2001, Pedroso et al. 2007, Assis et al. 2010), which estimates the losses caused by plant poisoning through records of these occurrences in the diagnostic laboratories in a given region, it is not possible to calculate how much these losses represent the total number of cases referred for diagnosis and the value of these deaths in relation to the expected percentage of all cause deaths for the herd of a particular region or country.

In Brazil, it is assumed that approximately $5 \%$ of cattle die annually from various causes (Riet-Correa \& Medeiros 2001, Pessoa et al. 2013). Considering that in the state of Mato Grosso do Sul, $1.4 \%$ of the cases of deaths referred for diagnosis are due to poisoning by $V$. rubricaulis (Souza et al. 2015), and that the State has 22.17 million heads (IBGE 2016), the annual death of cattle poisoned by this plant would be around 298 thousand animals, which would result in an annual loss of US $\$ 140,802,020.00$, considering the value animal monetary unit (\$ Vm) of US \$ 472.49.

Comparing the total number of deaths reported in this study over a 16-year period, the estimated injury was US $\$ 756,915.74$, or approximately US $\$ 47,307.23$ per year, showing a difference of $99.96 \%$ less than other methodologies (Nielsen 1978, Nielsen 1988, James et al. 1992, Riet-Correa \& Medeiros 2001, Assis et al. 2010, Pessoa et al. 2013, Zhao et al. 2013). Although part of this difference may be attributed to the underreporting of poisoning cases, the large variation in morbidity coefficients between outbreaks and the greater occurrence of outbreaks in certain years must also be considered.

Thus, the existence of an efficient notification system with standardized data is an indispensable tool for the elaboration of an efficient model for the evaluation of the economic losses caused by this poisoning.

Lack of higher numbers of accurate diagnosis by plant poisoning in livestock and lack of availability of more reliable data on disease outbreaks on the properties makes a more realistic estimation of the economics of cattle breeding (Nielsen 1978, Riet-Correa \& Medeiros 2001). Besides the lack of data on the economic impact of plant poisoning to livestock, there is still a lack of official government programs to control and minimize the losses caused by this problem (Rissi et al. 2007).

\section{CONCLUSIONS}

Poisoning by Vernonia rubricaulis in cattle has mortality ratios ranging from $0.25 \%$ to $41.21 \%$.

The outbreaks occur mainly from September to November and with an annual constancy in the state of Mato Grosso do Sul, Brazil.

The losses caused in cattle vary from $0.18 \%$ to $50.44 \%$ of the herd's total assets, and may cause serious economic impacts on rural properties.

Acknowledgements.- This work was financed by FUNDECT (Foundation for Support to the Development of Education) and CNPq (National Research Council), scholarship 15/2014; PRONEM-MS, scholarship 59/300.126/2015; FUNDECT-CAPES 05/2014 and PPVMS, scholarship 59/300.032/2015. And was financed in part by the Coordenação de Aperfeiçoamento de Pessoal de Nível Superior (CAPES), Brasil - Finance code 001.

Conflict of interest statement.- The authors have no competing interests.

\section{REFERENCES}

Assis T.S., Medeiros R.M.T., Riet-Correa F., Galiza G.J.N., Dantas A.F.M. \& Oliveira D.M. 2010. Intoxicações por plantas diagnosticadas em ruminantes e equinos e estimativa das perdas econômicas na Paraíba. Pesq. Vet. Bras. 30(1):13-20. <http://dx.doi.org/10.1590/S0100-736X2010000100003>

Brum K.B., Purisco E., Lemos R.A.A. \& Riet-Correa F. 2002. Intoxicação por Vernonia rubricaulis em bovinos no Mato Grosso do Sul. Pesq. Vet. Bras. 22(3):119-128. <http://dx.doi.org/10.1590/S0100-736X2002000300006>

Carmo P.M.S., Irigoyen L.F., Lucena R.B., Fighera R.A., Kommers G.D. \& Barros C.S.L. 2011. Spontaneous coffee senna poisoning in cattle: reporton 16 outbreaks. Pesq. Vet. Bras. 31(2):139-146. <http://dx.doi.org/10.1590/ S0100-736X2011000200008>

Carvalho N.M., Alonso L.A., Cunha T.G., Ravedutti J., Barros C.S.L. \& Lemos R.A.A. 2006. Intoxicação de bovinos por Tetrapterys multiglandulosa (Malpighiaceae) em Mato Grosso do Sul. Pesq. Vet. Bras. 26(3):139-146. <http://dx.doi.org/10.1590/S0100-736X2006000300002>

Dijkhuizen A.A., Huirne R.B.M. \& Jalvingh A.W. 1995. Economic analysis of animal diseases and their control. Prev. Vet. Med. 25(2):135-149. <http:// dx.doi.org/10.1016/0167-5877(95)00535-8>

FAO 2016. Economic analysis of animal diseases. FAO Animal Production and Health Guidelines No. 18, Food and Agriculture Organization of the United Nations, Rome.

Furlan F.H., Colodel E.M., Lemos R.A.A., Castro M.B., Mendonça F.S. \& RietCorrea F. 2012. Poisonous plants affecting cattle in central-western Brazil. Int. J. Pharmacogn. Phytochem. Res. 2:1-13.

Godoy K.C.S., Leal P.V., Araújo M.A., Souza A.I., Pott A., Lee S.T., Barros C.S.L. \& Lemos R.A.A. 2018. Experimental poisoning by Vernonia rubricaulis in sheep. Toxicon 141:9-14.

Gottschall C.S., Canellas L.C., Almeida M.R., Magero J. \& Bittencourt H.R. 2010. Principais causas de mortalidade na recria e terminação de bovinos de corte. Revta Acad. Ciênc. Agrar. Ambient. 8(3):327-332.

IBGE 2016. Produção da Pecuária Municipal. Vol. 44. Instituto Brasileiro de Geografia e Estatística. Available at <https://biblioteca.ibge.gov.br/ visualizacao/periodicos/84/ppm_2016_v44_br.pdf> Accessed on Jun. 29, 2018.

James L.F., Nielsen D.B. \& Panter K.E. 1992. Impact of poisonous plants on the livestock industry. J. Range Management 45(1):3-8. <http://dx.doi. org/10.2307/4002517>

Lemos R.A.A., Nogueira A.P.A., Souza R.I.C., Santos B.S., Carvalho N.M., Aniz A.C.M. \& Freitas P.C. 2011. Hepatotoxic plants, p.70. In: Riet-Correa F., Pfister J., Schild A.L. \& Wierenga T. (Eds), Poisoning by Plants, Mycotoxins and Related Toxins. CABI, London.

Nielsen D.B. 1978. The economic impact of poisonous plants on the range livestock industry in the 17 western states. J. Range Management 31(5):325327. <http://dx.doi.org/10.2307/3897353>

Nielsen D.B. 1988. Economic impact of poisonous plants on the rangeland livestock industry. J. Anim. Sci. 66(9):2330-2333. <http://dx.doi.org/10.2527/ jas1988.6692330x $><$ PMid:3170376>

Pedroso P.M.O., Pescador C.A., Oliveira E.C., Sonne L., Bandara P.M., Raymundo D.L. \& Driemeier D. 2007. Intoxicações naturais por plantas em ruminantes diagnosticadas no setor de patologia veterinária da UFRGS no período de 1996-2005. Acta Scient. Vet. 35(2):213-218.

Perry B., McDermott J. \& Randolph T. 2001. Can epidemiology and economics make a meaningful contribution to national animal-disease control? Prev. Vet. Med. 48(4):231-260. <http://dx.doi.org/10.1016/S0167-5877(00)00203$8><$ PMid:11259818>

Pessoa C.R.M., Medeiros R.M.T. \& Riet-Correa F. 2013. Importância econômica, epidemiologia e controle das intoxicações por plantas no Brasil. Pesq. Vet. Bras. 33(6):752-758. <http://dx.doi.org/10.1590/S0100-736X2013000600011> 
Pötter L., Lobato J.F.P. \& Mielitz Netto C.G.A. 2000. Análises econômicas de modelos de produção com novilhas de corte primíparas aos dois, três e quarto anos de idade. Revta Bras. Zootec. 29(3):861-870. <http://dx.doi. org/10.1590/S1516-35982000000300032>

Purisco E. \& Lemos R.A.A. 2008. Intoxicação por Vernonia sp., p.245-248. In: Lemos R.A.A. \& Brito C.R.L. (Eds), Doenças de Impacto Econômico em Bovinos de Corte, Perguntas e Respostas. Editora UFMS, Campo Grande.

Riet-Correa F. \& Medeiros R.M.T. 2001. Intoxicações por plantas em ruminantes no Brasil e no Uruguai: importância econômica, controle e riscos para a saúde pública. Pesq. Vet. Bras. 21(1):38-42. <http://dx.doi.org/10.1590/ S0100-736X2001000100008>

Rissi D.R., Rech R.R., Pierezan F., Gabriel A.L., Trost M.E., Brum J.S., Kommers G.D. \& Barros C.S.L. 2007. Intoxicações por plantas e micotoxinas associadas a plantas em bovinos no Rio Grande do Sul: 461 casos. Pesq. Vet. Bras. 27(7):261-268. <http://dx.doi.org/10.1590/S0100-736X2007000700002>
Smith R.A. 1998. Impact of disease on feedlot performance: a review. J. Anim. Sci. 76(1):272-274. <http://dx.doi.org/10.2527/1998.761272x> <PMid:9464908>

Souza R.I.C., Santos A.C., Ribas N.L.K.S., Colodel E.M., Leal P.V., Pupin R.C., Carvalho N.M. \& Lemos R.A.A. 2015. Doenças tóxicas de bovinos em Mato Grosso do Sul. Semina, Ciênc. Agrárias 36(3):1355-1368.

Tokarnia C.H. \& Döbereiner J. 1982. Intoxicação de Bovinos por Vernonia rubricaulis (Compositae) em Mato Grosso. Pesq. Vet. Bras. 2(4):143-147.

Tokarnia C.H., Brito M.F., Barbosa J.D., Peixoto P.V. \& Döbereiner J. 2012. Plantas Tóxicas do Brasil para Animais de Produção. $2^{\text {a }}$ ed. Heliantus, Rio de Janeiro, p.167-169.

Zhao M., Gao X., Wang J., He X. \& Han B. 2013. A review of the most economically important poisonous plants to the livestock industry on temperate grasslands of China. J. Appl. Toxicol. 33(1):9-17. <http://dx.doi. org/10.1002/jat.2789> <PMid:23015535> 